\title{
KAJIAN KUAT LENTUR BETON PADA PERKERASAN KAKU JALAN TOL BALIKPAPAN-SAMARINDA
}

\author{
Rahmat $^{\left(1^{*}\right)}$, Irna Hendriyani ${ }^{(2)}$, Ryandi Dito Pratama ${ }^{(3)}$ \\ Program Studi Teknik Sipil Universitas Balikpapan \\ *) E-mail: rhtrusli@gmail.com
}

\begin{abstract}
ABSTRAK
Jalan tol Balikpapan - Samarinda merupakan salah satu bagian jalan tol trans Kalimantan yang sampai saat ini dalam tahap pembangunan. Pembangunan jalan tol ini menggunakan perkerasan kaku. Perencanaan jalan tol ini oleh Dinas Pekerjaan Umum Provinsi Kalimantan Timur, mensyaratkan memiliki kuat lentur minimal 45 $\mathrm{kg} / \mathrm{cm}^{2}$ untuk umur beton 28 hari. Karenanya tujuan dari penelitian ini adalah melakukan kajian pada kuat lentur beton pada perkerasan kaku jalan tol Balikpapan-Samarinda berdasarkan perencanaan campuran beton di lapangan. Penelitian ini menggunakan metode eksperimen di laboratorium. Sampel pengujian dibuat berdasarkan perencanaan adukan beton yang digunakan di lapangan dan dilakukan pengujian di laboratorium. Sampel yang digunakan sebanyak 12 buah untuk silinder ukuran $15 \times 30$, dan 12 buah untuk balok ukuran $15 \times 15 \times 60$, yang akan diuji pada umur 7, 14, 21, dan 28 hari. Hasil pengujian kuat tekan pada silinder didapatkan sebesar 382 $\mathrm{kg} / \mathrm{cm}^{2}$, lebih besar $27 \%$ dari perencaaan, dan kuat lentur pada balok sebesar 53,48 kg/cm ${ }^{2}$, lebih besar $18 \%$ dari persyaratan. Maka dapat disimpulkan bahwa pekerjaan perkerasan kaku pada jalan tol Balikpapan-Samarinda telah sesuai dengan persyaratan yang telah ditetapkan oleh Dinas Pekerjaan Umum Provinsi Kalimantan Timur.
\end{abstract}

Kata kunci: kuat lentur beton, kuat tekan beton, dan perkerasan kaku. 
Kajian Kuat Lentur Beton pada Perkerasan Kaku...Rahmat ${ }^{(1)}$, Irna $\mathrm{H}^{(2)}$, Ryandi ${ }^{(3)}$

\section{PENDAHULUAN}

Jalan merupakan salah satu prasarana perhubungan darat yang mempunyai peranan penting bagi pertumbuhan perekonomian, sosial budaya, pengembangan wilayah pariwisata, dan pertahanan keamanan untuk menunjang pembangunan nasional. Untuk itu diperlukan pembangunan jaringan jalan yang memadai agar mampu memberikan pelayanan yang optimal sesuai dengan kapasitas yang diperlukan. Selain perencanaan geometrik jalan, perkerasan jalan merupakan bagian dari perencanaan jalan yang harus direncanakan secara efektif dan efisien, karena kebutuhan tingkat pelayanan jalan semakin tinggi, maka perlu adanya peningkatan kualitas sistem dan prasaran jalan, diantaranya adalah kebutuhan jalan yang aman dan nyaman.

Jalan tol Balikpapan - Samarinda merupakan salah satu bagian jalan tol trans Kalimantan yang sampai saat ini masih dalam tahap pembangunan. Pembangunan jalan tol ini menggunakan perkerasan kaku. Perkerasan kaku adalah perkerasan yang menggunakan semen sebagai bahan ikat sehingga mempunyai tingkat kekakuan yang cukup tinggi. Perencanaan jalan tol Balikpapan - Samarinda menggunakan metode Bina Marga mensyaratkan pengujian kuat lentur minimal $45 \mathrm{~kg} / \mathrm{cm}^{2}$ untuk umur beton 28 hari yang tercantum dispesifikasi jalan tol Balikpapan Samarinda.

Permasalahan dalam penelitian ini adalah bagaimana hasil pengujian kuat tekan dan kuat lentur beton berdasarkan proporsi campuran pada perkerasan kaku jalan tol Balikpapan-Samarinda? Apakah hasil pengujian tersebut telah memenuhi persyaratan yang ditetapkan Dinas Pekerjaan Umum Provinsi Kalimantan Timur?

Maka tujuan dari penelitian ini adalah melakukan kajian pengujian kuat tekan dan kuat lentur beton berdasarkan proporsi campuran pada perkerasan kaku jalan tol Balikpapan-Samarinda. Kemudian membandingkan dengan persyaratan yang telah ditetapkan Dinas Pekerjaan Umum Provinsi Kalimantan Timur, yaitu memiliki kuat lentur beton minimal $45 \mathrm{~kg} / \mathrm{cm}^{2}$.

\section{TINJAUAN PUSTAKA}

\section{Perkerasan Kaku}

Rigid pavement atau perkerasan kaku adalah jenis perkerasan jalan yang menggunakan

beton sebagai bahan utama perkerasan tersebut, merupakan salah satu jenis perkerasan jalan yang digunakan selain dari perkerasan lentur (asphalt). Perkerasan ini umumnya dipakai pada jalan yang memiliki kondisi lalu lintas yang cukup padat dan memiliki distribusi beban yang besar, seperti pada jalan-jalan lintas antar provinsi, jembatan layang (fly over) jalan tol, maupun pada persimpangan bersinyal.

Jalan-jalan tersebut umumnya menggunakan beton sebagai bahan perkerasannya, namun untuk meningkatkan kenyamanan biasanya diatas permukaan perkerasan dilapisi asphalt. Keunggulan dari perkerasan kaku sendiri dibanding perkerasan lentur (asphalt) adalah bagaimana distribusi beban disalurkan ke subgrade.

Perkerasan kaku karena mempunyai kekakuan, akan mendistribusikan beban pada daerah yang relatif luas pada subgrade, beton sendiri bagian utama yang menanggung beban struktural. Sedangkan pada perkerasan lentur karena dibuat dari material yang kurang kaku, maka persebaran beban yang dilakukan tidak sebaik pada beton. Sehingga memerlukan ketebalan yang lebih besar. Hal ini seperti tergambar pada Gambar 1.

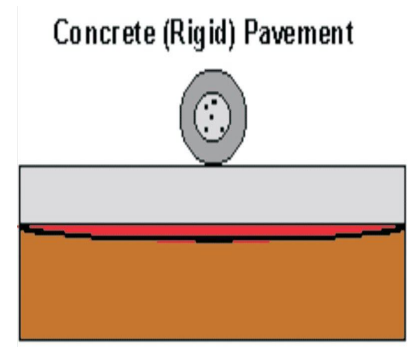

Gambar 1 Distribusi pembebanan pada perkerasan kaku dan perkerasan lentur

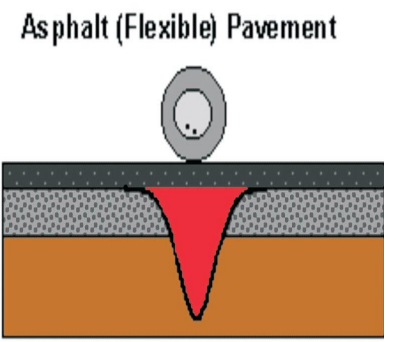

asi Jalan Tol Bina Marga, 2015.

Pada kontruksi perkerasan kaku, perkerasan tidak dibuat menerus sepanjang jalan seperti halnya yang dilakukan pada perkerasan lentur. Hal ini dilakukan untuk mencegah terjadinya pemuaian yang besar pada permukaan perkerasan sehingga dapat menyebabkan retaknya perkerasan, selain itu kontruksi seperti ini juga dilakukan untuk mencegah terjadinya retak menerus pada perkerasan jika terjadi keretakan pada suatu titik pada perkerasan. Salah satu cara yang digunakan untuk mencegah terjadi hal diatas adalah dengan cara 
Kajian Kuat Lentur Beton pada Perkerasan Kaku...Rahmat ${ }^{(1)}$, Irna $\mathrm{H}^{(2)}$, Ryandi ${ }^{(3)}$

membuat kontruksi segmen pada perkerasan kaku dengan sistem joint untuk menghubungkan tiap segmennya.

\section{Material Campuran Beton}

Perencanaan campuran beton merupakan kunci dihasilkan beton yang baik, akan tetapi yang namanya kunci pastilah memiliki gigi-gigi kunci yang lainnya kira-kira seperti itulah perumpamanya. Berawal dari proporsi campuran beton yang baik (inilah yang dimaksud dengan kunci) dan masih didukung oleh faktor yang lainnya yaitu pencampuran, pengecoran, pemadatan dan perawatan beton paska pengecoran (inilah yang dimaksud dengan gigi-gigi kunci yang lain).

Sebagai definisi yang telat kita ungkapkan bahwa beton merupakan persenyawaan yang terdiri dari agregat, air, semen dan zat tambahan jika diperlukan syarat khusus maka kendali proporsi material beton harus kita ketahui.

Menurut aturan yang berlaku di Indonesia dan secara teoritis perencanaan campuran beton bukanlah hal yang mudah, disamping harus menguasai disiplin ilmu teknik sipil terutama tentang teknologi bahkan kontruksi, juga diperlukan laboratorium untuk menganalisa material yang akan kiat gunakan dan juga diperlukan lab untuk menguji hasil perencanaan campuran beton.

\section{Semen PCC}

Semen ini adalah semen Portland yang masuk kedalam kategori semen campur. Semen campur ini dibuat atau didesign karena dibutuhkannya sifat-sifat tertentu yang mana sifat tersebut tidak dimiliki oleh semen portland tipe I. Untuk mendapatkan sifat-sifat tertentu pada semen campur maka pada proses pembuatannya ditambahkan bahan aditif seperti Pozzolan, Fly ash, silica fume, dan lain-lain.

Menurut SNI 15 7064.2004 maka definisi Semen Portland Composite adalah bahan pengikut hidrolisis hasil penggilingan bersama-sama terak semen portland dan gyps dengan satu atau lebih bahan anorganik atau hasil pencampuran antara bubuk semen portland dengan bubuk bahan anorganik lain.

Bahan anorganik tersebut antara lain Terak Tanur Tinggi (Blast Furnace Slag), pozzolan, senyawa silicat, batu kapur dengan kadar total bahan anorganik 6\% - 35\% dari massa semen portland komposite.

Sifat-sifat yang dimiliki Semen PCC :

1. Mempunyai panas hindrasi rendah sampai sedang.

2. Tahan terhadap serangan sulfat.

3. Kekuatan tekan awal kurang, namun kekuatan akhir lebih tinggi.

4. Dintinjau dari sifat yang dimiliki oleh Semen PCC maka semen tersebut dapat digunakan sebagai alternatif atau pengganti semen portland tipe II,IV atau V.

Standar acuan yang digunakan semen portland komposit bersumber dari EN-197-1, Europen Standard CEM II Portland Composite Cement. Menurut EN 197-1 Portland Composite Cement CEM II terbagi 2 yaitu :

1. CEM II/ A-M, komposisi semen ini terdiri dari, 80 - 90\% klinker/terak, 6 - 20\% bahan anorganik (Blast Furnace, silica fume, pozzolan, flyash, burn shale lime stone), 0 $5 \%$ bahan tambahan minor (gypsum)

2. CEM II/B-M, komposisi semen ini terdiri dari, $65-79 \%$ klinker/terak, 21 - $35 \%$ bahan anorganik (Blast Furnance, silica fume, pozzolan, flyash, burn shale lime stone), 0 $5 \%$ bahan tambahan minor (gypsum).

Sedangkan kalau mengacu ke standard ASTM maka standard yang digunakan adalah ASTM C 595, Specification for Blended Cement. Menurut standard ini maka blended cement terbagi menjadi :

1. Tipe IS = Portland Blast Furnance Slag Cement

2. Tipe IP = Portland Pozzolan Cement

3. Tipe $\mathrm{P}=$ Portland Pozzolan Cement digunakan ketika beton mutu tinggi pada umut awal.

Sedangkan menurut SNI maka semen PCC mengacu pada SNI 15 7064, Semen Portland Composite.

Air

Air yang digunakan untuk beton harus disetujui oleh konsultan pengawas. Air yang dipergunakan dalam pencampuran, pengawetan, atau pekerjaan lainnya harus bersih dari minyak, 
Kajian Kuat Lentur Beton pada Perkerasan Kaku...Rahmat ${ }^{(1)}$, Irna $\mathrm{H}^{(2)}$, Ryandi ${ }^{(3)}$

garam, asam, alkali, gula, tumbuhan atau zat lainnya yang merusak hasil pekerjaan. Bila diminta oleh konsultan pengawas, air harus diuji dengan diperbandingan terhadap air suling. Perbandingan harus memakai cara uji semen standar untuk kekerasan, waktu pembuatan (setting time), dan kekuatan adukan.

Petunjuk dari kekerasan, perubahan waktu pengikut \pm 30 menit atau lebih, penyusutan kekuatan adukan lebih dari 10\% dibandingkan dengan air suling, cukup menjadi alasan ditolaknya air yang tengah diuji itu. Bila sumber air dangkal pemngambilannya harus sedemikian rupa agar lumpur, rumput, atau bahan asing lainnya tidak ikut terbawa.

\section{Agregat Halus}

Agregat halus untuk beton harus terdiri dari pasir alam atau material lembut lainnya dengan sifat sama, mempunya butir bersi, keras dan awet, serta harus bersih dan bebas dari debu, lumpur, lempung, bahan organik, dan kotoran lainnya, dalam jumlah melebihi batas toleransi. Agregat halus harus bergradasi merata dan harus memenuhi ketentuan gradasi seperti pada Tabel 1.

Tabel 1 Gradasi Agregat Halus yang Ditentukan Bina Marga

\begin{tabular}{cc}
\hline Ukuran saringan (mm) & $\begin{array}{c}\text { Kumulatif presentase } \\
\text { berat yang lolos }\end{array}$ \\
\hline 9,5 & 100 \\
\hline 4,75 & $95-100$ \\
\hline 2,36 & $80-100$ \\
\hline 1,18 & $50-85$ \\
\hline 0,600 & $25-60$ \\
\hline 0,300 & $10-30$ \\
\hline 0,150 & $2-10$ \\
\hline Sumber : Spesifikasi Jalan Tol Bina Marga, 2015.
\end{tabular}

Dan untuk sifat-sifat agregat halus adalah seperti pada Tabel 2.

Tabel 2 Sifat agregat Halus yang Ditentukan Bina Marga

\begin{tabular}{clc}
\hline No. & \multicolumn{1}{c}{ Zat } & Maksimum \\
\hline 1 & $\begin{array}{l}\text { Gumpalan lempung dan } \\
\text { material yang mudah pecah } \\
\text { (AASHTO T 112) }\end{array}$ & 3,0 \\
\hline 2 & $\begin{array}{l}\text { Material halus yang lolos dari } \\
\text { saringan 0,0075 }\end{array}$ & 3,0 \\
& $\begin{array}{l}\text { Beton yang akan mengalami } \\
\text { abrasi beton lainnya }\end{array}$ & 5,0 \\
\hline
\end{tabular}

\begin{tabular}{clcc}
\hline No. & \multicolumn{2}{c}{ Zat } & Maksimum \\
\hline 3 & $\begin{array}{l}\text { Material yang mengapung } \\
\text { dalam cairan specific gravity }\end{array}$ & 0,5 \\
& 1,95 \\
\hline Sumber : Spesifikasi Jalan Tol Bina Marga, 2015.
\end{tabular}

\subsubsection{Agregat kasar}

Agregat kasar harus terdiri dari satu atau lebih dari satu material berikut : batu pecah, kerikil, ampas tanur tinggi, atau material lambam lainnya yang disetujui dengan sifat yang sama, mempunyai dengan sifat yang sama, mempunyai butir-butir yang bersih, keras dan awet.

Agregat kasar harus bersih dan bebas dari butiranbutiran yang panjang atau bulat, bahan organik dan bahan pengganggu lainnya dalam melebihi batas toleransi. Untuk gradasi agregat kasar seperti pada Tabel 3.

Tabel 3 Gradasi agregat kasar yang Ditentukan Bina Marga

\begin{tabular}{|c|c|c|c|c|c|c|c|c|c|c|c|}
\hline \multirow{3}{*}{$\begin{array}{c}\text { Ukuran } \\
\text { Agregat } \\
\text { Kasar }\end{array}$} & \multirow{2}{*}{\multicolumn{11}{|c|}{$\begin{array}{c}\text { Jumlah yang lebih halus dari saringan standar } \\
\text { masing-masing persentase herat (JS A 1102) AASHTO T27 }\end{array}$}} \\
\hline & & & & & & & & & & & \\
\hline & $100 \mathrm{~mm}$ & $80 \mathrm{~mm}$ & $60 \mathrm{~mm}$ & $50 \mathrm{~mm}$ & $40 \mathrm{~mm}$ & $25 \mathrm{~mm}$ & $20 \mathrm{~mm}$ & $15 \mathrm{~mm}$ & $10 \mathrm{~mm}$ & $5 \mathrm{~mm}$ & $2,5 \mathrm{~mm}$ \\
\hline 50.5 & . & . & 100 & 95.100 & . & $37-70$ & . & 10.35 & . & 0.5 & . \\
\hline 40.5 & . & . & . & 100 & 95.100 & . & 35.70 & . & $10-30$ & 0.5 & . \\
\hline 25.5 & . &. & . & . & 100 & $95 \cdot 100$ & . & $30-70$ & . & 0.10 & 0.5 \\
\hline 20.5 & . & . & . & . & . & 100 & $90-100$ & . & $20-55$ & 0.10 & 0.5 \\
\hline 15.5 & . & . & . & . & . & . & 100 & $90-100$ & 40.70 & 0.15 & 0.5 \\
\hline 80.40 & 100 & 90.100 & 45.70 & . & 0.15 & . & 0.5 & . & . & . & . \\
\hline $60-40$ & . & 100 & 90.100 & 45.70 & 0.15 & . & 0.5 & . & . & . & . \\
\hline $50-25$ & . & . & 100 & 90.100 & $35 \cdot 70$ & 0.15 & . & 0.5 & . & . & . \\
\hline $40-20$ & . & . & . & 100 & $90 \cdot 100$ & 20.55 & 0.15 & . & 0.5 & . & . \\
\hline
\end{tabular}

Sumber : Spesifikasi Jalan Tol Bina Marga, 2015.

Agregat kasar harus mempunyai ketahanan abrasi dengan mesin Los Angeles tidak lebih dari $30 \%$ sesuai dengan pengujian AASHTO T 96 dan kekekalan agregat tidak lebih dari $12 \%$ dengan sodium sulfat atau tidak lebih dari $18 \%$ dengan magnesium sulfat sesuai dengan pengujian AASHTO T 104.

Sementara sifat-sifat agregat kasar harus seperti pada Tabel 4.

Tabel 4 Sifat agregat kasar yang Ditentukan Bina Marga

\begin{tabular}{clc}
\hline No. & \multicolumn{1}{c}{ Zat } & Maksimum \\
\hline 1 & $\begin{array}{l}\text { Gumpalan lempung dan } \\
\text { material yang mudah pecah } \\
\text { (AASHTO T 112) }\end{array}$ & 2,0 \\
\hline 2 & $\begin{array}{l}\text { Material halus yang lolos dari } \\
\text { saringan 0,0075 }\end{array}$ & 1,0 \\
\hline 3 & Material yang mengapung & 1,0 \\
\hline
\end{tabular}


Kajian Kuat Lentur Beton pada Perkerasan Kaku...Rahmat ${ }^{(1)}$, Irna $\mathrm{H}^{(2)}$, Ryandi ${ }^{(3)}$

\begin{tabular}{ccc}
\hline No. & Zat & Maksimum \\
\hline \multicolumn{2}{c}{ dalam cairan specific gravity } \\
1,95
\end{tabular}

Sumber : Spesifikasi Jalan Tol Bina Marga, 2015

\section{Pengujian Material}

Untuk menghasilkan produk beton yang maksimal material yang digunakan harus yang terbaik, murah dan sesuai dengan spesifikasi yang ditentukan oleh Bina Marga maka diadakan pengujian material yaitu agregat kasar, agregat halus dan pasir Palu.

Semua material tersebut harus ditest abrasi, kadar lumpur dan gradasinya, apakah sudah sesuai syarat yang ditentukan. Jenis test yang dilaksanakan adalah sebagai berikut :

\section{Test Abrasi}

Untuk mengetahui keausan material yang dipakai harus diadakan test abrasi pemeriksaan keausan agregat adalah untuk mengetahui angka keausan suatu agregat, yang dinyatakan dengan perbandingan antara berat bahan yang aus yaitu lolos saringan No. $12(1,7 \mathrm{~mm})$ terhadap berat mula-mula, dalam persen (\%), dan juga sebagai pegangan untuk menentukan ketahanan agregat kasar terhadap keausan dengan mengunakan mesin abrasi Los Angeles.

Pemeriksaan ini dapat digunakan untuk menentukan keausan agregat kasar. Hasil pengujian bahan ini pada umumnya dapat dipergunakan dalam perencanaan dan pelaksanaan bahan perkerasan jalan atau konstruksi beton.

Berdasarkan SK SNI 2417 - 1991, keausan agregat tergolong sebagai berikut :

1. Apabila nilai keausan yang diperoleh $>40 \%$, maka agregat yang diuji tidak baik digunakan dalam bahan perkerasan jalan.

2. Apabila nilai keausan agregat yang diperoleh $<40 \%$, maka agregat yang diuji baik digunakan dalam bahan perkerasan jalan.

Peralatan untuk pelaksanaan pengujian adalah sebagai berikut :

1. Mesin Abrasi Los Angeles. Mesin ini terdiri dari silinder baja tertutup pada kedua sisinya dengan diameter $711 \mathrm{~mm}$.
2. Panjang dalam $508 \mathrm{~mm}$ silinder bertumpu pada dua poros pendek yang tidak menerus dan berputar pada poros mendatar

3. Silinder berlubang untuk memasukkan benda uji.

4. Penutup lubang tetutup dengan rapat sehingga permukaan dalam silinder tidak terganggu.

5. Dibagian dalam silinder tersebut terdapat bilah baja melintang penuh setinggi $89 \mathrm{~mm}$.

6. Bola-bola baja dengan diameter rata-rata 4,68 $\mathrm{cm}$ (I 7/8") dan berat masing - masing antara 400 gram sampai 440 gram.

7. Saringan No. $12(1,7 \mathrm{~mm})$ dan saringan-saringan lainnya).

8. Neraca / Timbangan, dengan ketelitian 5 gram (timbangan digital).

9. Oven yang dilengkapi dengan pengatur suhu untuk memanasi sampai $(110 \pm \mathrm{S})^{\circ} \mathrm{C}$.

Benda uji yang digunakan dalam test ini harus diadakan pengambilan secara acak untuk mewakili material yang akan digunakan. Benda uji dipersiapkan dengan cara sebagai berikut :

1. Berat dan gradasi benda uji sesuai

2. Bersihkan benda uji dan keringkan dalam oven pada suhu $(110 \pm 5)^{\circ} \mathrm{C}$.

Cara Pengujian yang dilaksanakan untuk test abrasi material yang dilaksanakan ada beberapa macam. Pengujian ketahanan agregat kasar terhadap keausan dapat dilakukan dengan salah satu dari 7 cara ini:

a. Cara A : Gradasi A, bahan lolos 37,5 mm sampai tertahan, $5 \mathrm{~mm}$. Jumlah bola 12 buah dengan 500 putaran.

b. Cara B : Gradasi B, bahan lolos $19 \mathrm{~mm}$ sampai tertahan $9,5 \mathrm{~mm}$. Jumlah bola 11 buah dengan 500 putaran.

c. Cara C : Gradasi C, bahan lolos 9,5 mm sampai tertahan $4,75 \mathrm{~mm}$ (no.4), jumlah bola 8 buah dengan 500 putaran.

d. Cara D : Gradasi D, bahan lolos 4,75 mm (no. 4) sampai tertahan 2,36 mm (no. 8). Jumlah bola 6 buah dengan 500 putaran.

e. Cara E : Gradasi E, bahan lolos $75 \mathrm{~mm}$ sampai tertahan $37,5 \mathrm{~mm}$. Jumlah bola 12 buah dengan 1000 putaran. 
Kajian Kuat Lentur Beton pada Perkerasan Kaku...Rahmat ${ }^{(1)}$, Irna $\mathrm{H}^{(2)}$, Ryandi ${ }^{(3)}$

f. Cara F : Gradasi F, bahan lolos $50 \mathrm{~mm}$ sampai tertahan $25 \mathrm{~mm}$. Jumlah bola 12 dengan 1000 putaran.

g. Cara G : Gradasi G, bahan lolos 37,5 mm sampai tertahan $19 \mathrm{~mm}$ Jumlah bola 12 buah dengan 1000 putaran.

Apabila tidak ditentukan cara yang harus dilakukan, maka pemilihan gradasi disesuaikan dengan contoh material yang merupakan wakil dari material yang akan dipakai.

a. Benda uji dan bola baja dimasukkan ke dalam mesin Abrasi Los Angeles

b. Putar mesin dengan kecepatan 30 sampai dengan $33 \mathrm{rpm}$. Jumlah putaran gradasi A, B, C, dan D 500 putaran dan untuk gradasi E, F, dan G 1000 putaran.

c. Sesudah pemutaran, keluarkan benda uji dari mesin lalu saring dengan saringan no. $12(1,7$ $\mathrm{mm})$. butiran yang tertahan disaringan dicuci bersih. selanjutnya dikeringkan dalam oven pada suhu $(110 \pm 5)^{\circ} \mathrm{C}$ sampai berat tetap.

Perhitungan hasil test abrasi dengan rumus yang sudah ditentukan adalah dengan

Keausan $=\frac{\mathrm{A}-\mathrm{B}}{\mathrm{A}} \times 100 \%$

Keterangan :

$A=$ berat benda uji semula, gram.

$\mathrm{B}=$ berat benda uji tertahan saringan no.12, gram.

\section{Test Kadar Air}

Test kadar air adalah perbandingan kadar air pada saat keadaan normal kemudian dikurangi pada saat sudah dalam keadaan benar-benar kering. Test tersebut sangat mempengaruhi dalam pembuatan beton karena hasil test kadar air material yang digunkanlah sebagai acuan kita dalam menentukan jumlah air pada saat pembuatan beton. Cara perhitungan untuk mengetahui kadar air material adalah :

Kadar Air (\%)

$=\frac{\text { Corat basah material-Berat Kering }}{\text { Barat Bnsah }} \times 100$

\section{Test Gradasi}

Analisa saringan adalah pengelompokan besar butir analisa agregat kasar dan agregat halus menjadi komposisi gabungan yang ditinjau berdasarkan saringan.

Adapun tujuan dari analisa saringan yaitu :

a. Untuk mendapatkan beton yang mudah dikerjakan ( diaduk, dialirkan, dan didapatkan) yang mempunyai tingkat workability yang tinggi.

b. Untuk mendapatkan harga beton yang ekonomis, kekuatan tinggi.

c. Untuk mendapatkan baton yang betul - betul padat.

d. Untuk mendapatkan batas gradasi dari agregat.

e. Untuk mendapatkan komposisi campuran analisa agregat kasar dan agregat halus dalam bentuk ideal.

Bentuk-bentuk gradasi agregat :

a. Well gradet (bergradasi baik).

b. Gap gradet (bergradasi terputus).

c. Uniform gradet (bergradasi beragam).

Gradasi agregat halus sangat penting peranannya dalam suatu konstruksi yang berkualitas karena gradasi ini berpengaruh terhadap sifat beton. Adapun sifat beton itu adalah :

a. Terhadap beton keras

Bila beton segar sukar untuk didapatkan, maka akan terjadi gradasi sehingga menghasilkan beton kropos dan tidak kedap terhadap air, banyak rongga yang menyebabkan kekuatan dan ketahanan beton berkurang.

b. Terhadap beton segar

1. Mempengaruhi sifat kohesif.

2. Sebagai kontrol terhadap agregat.

3. Mempengaruhi jumlah air pencampur dan jumlah PC untuk suatu campuran beton.

4. Mempengaruhi kelecakan.

5. Mempengaruhi keadaan permukaan.

Ukuran maksimal agregat ada 3, yaitu 40, 30, dan $10 \mathrm{~mm}$. Tujuan mendapatkan ukuran maksimal agregat adalah untuk mengetahui batas gradasi. Berikut adalah hasil test gradasi material agregat kasar.

Karena jenis agregat ksar yang digunakan ada dua jenis yaitu agregat $1-2$ dan agregat $2-3$, maka diadakan 2 test yang terpisah dan akan dirincikan masing-masing. 
Kajian Kuat Lentur Beton pada Perkerasan Kaku...Rahmat ${ }^{(1)}$, Irna $\mathrm{H}^{(2)}$, Ryandi ${ }^{(3)}$

\section{Test Absorption}

Berat jenis (Specific Gravity) agregat berbeda satu sama lainnya,tergantung dari jenis batuan, susunan mineral, struktur butiran, dan porositas batuannya. Berat jenis (Specific Gravity) agregat mempunyai arti yang sangat penting terhadap sifat beton yang dibuatnya. Berat jenis Absolut (Absolut Specipic Gravity) adalah perbandingan antara suatu masa yang masip dengan berat air murni pada volume yang sama dan suhu tertentu.

Disini volume benda adalah volume masif tidak termasuk pori-pori didalamnya (permeable dan impermeable). Pada umumnya agregat mengandung pori-pori, sehingga bila ingin mendefinisikan Berat Jenis (Specific Gravity) agregat harus dikaitkan dengan hal ini, oleh karena itu berat jenis (Specific Gravity) agregat dikenal:

1. Berat Jenis Curah atau Kering (Bulk Specific Gravity) adalah perbandingan antara berat agregat kering dan berat air suling yang isinya sama dengan isi agregat dalam keadaan jenuh pada suhu $25^{\circ} \mathrm{C}$.

2. Berat Jenis Kering Permukaan Jenuh (SSD Specific Gravity)adalah perbandinganantara berat agregat kering permukaan jenuh dan berat air suling yang isinya sama dengan isi agregat dalam keadaan jenuh pada suhu $25^{\circ} \mathrm{C}$.

3. Berat Jenis Semu (Apparent Specific Gravity) adalah perbandingan antara berat agregat kering dan berat air suling yang isinya sama dengan isi agregat dalam keadaan kering pada suhu $25^{\circ} \mathrm{C}$.

\section{Campuran Beton}

Kuat lentur beton yang direncanakan dalam penelitian ini adalah $45 \mathrm{~kg} / \mathrm{cm}^{2}$ (Tabel 5). Penelitian ini dilaksanakan di Laboratorium Teknik Sipil dan Perencanaan Universitas Balikpapan dengan benda uji bentuk balok dan silinder.

Tabel 5 Proporsi campuran yang sudah ditentukan Bina Marga

\begin{tabular}{lc}
\hline $\begin{array}{l}\text { Ukuran maksimum } \\
\text { agregat kasar }\end{array}$ & $25 \mathrm{~mm}$ \\
\hline Slump & Max $25 \mathrm{~cm}$ \\
\hline $\begin{array}{l}\text { Perbandingan air semen } \\
\text { W/C }\end{array}$ & $40 \%$ \\
\hline Kadar air $(\mathrm{W})$ & $160 \mathrm{Kg} / \mathrm{cm}^{2}$ \\
\hline Kadar semen $(\mathrm{C})$ & $400 \mathrm{Kg} / \mathrm{cm}^{2}$ \\
\hline
\end{tabular}

\begin{tabular}{lc}
\hline Agregat halus (S) & $791 \mathrm{Kg} / \mathrm{cm}^{2}$ \\
\hline Agregat kasar (G) & $1,077 \mathrm{Kg} / \mathrm{cm}^{2}$ \\
\hline $\begin{array}{l}\text { Kekuatan lentur minimal } \\
\text { waktu } 28 \text { hari }\end{array}$ & $45 \mathrm{Kg} / \mathrm{cm}^{2}$ \\
\hline
\end{tabular}

Sumber : Spesifikasi Jalan Tol Bina Marga, 2015

Proses memilih bahan-bahan pembetonan yang tepat dan memutuskan jumlah/kuantitas ketergantungan dari bahan-bahan tersebut dengan mempertimbangkan syarat mutu beton, strength, durability dan kemudahan pengerjaan workability serta nilai ekonomisnya.

Setelah mendapatkan hasil dari test material yang akan digunakan maka selanjutnya akan dibuat mix design Rancangan campuran (Job Mix Design) beton dilakukan menghasilkan suatu komposisi penggunaan bahan yang minimum dengan kekuatan yang maksimal dengan tetap mempertimbangkan kriteria standar mutu beton dan ekonomis jika ditinjau dari aspek biaya keseluruhannya.

Di Indonesia metode yang digunakan untuk Job Mix Design merupakan adopsi dari British Standard atau Departement of Environment (DoE) yang dimuat dalam buku standar No. SK. SNI. T15-1990-03.

Kriteria dasar dalam perancangan beton adalah kekuatan tekan beton yang berhubungan dengan faktor air semen yang digunakan. Menurut Neville (1981), untuk menghasilkan kekuatan yang tinggi maka penggunaan air dalam campuran beton harus minimum.

\section{Flexural Strength Test}

Flexural strength test atau Kuat tarik lentur adalah kemampuan balok beton yang diletakkan pada dua perletakan untuk menahan gaya dengan arah tegak lurus sumbu benda uji, yang diberikan padanya, sampai benda uji patah yang dinyatakan dalam $\mathrm{kg} / \mathrm{cm}^{2}$ gaya tiap satuan luas (SNI 03-44311997).

Sebuah balok yang diberi beban akan mengalami deformasi, dan oleh sebab itu timbul momen-momen lentur sebagai perlawanan dari material yang membentuk balok tersebut terhadap beban luar. Tegangan yang timbul selama mengalami deformasi tidak boleh melebihi tegangan lentur ijin untuk beban dari beton itu. 
Momen eksternal harus ditahan oleh bahan dari beton, dan harga maksimum yang dapat dicapai sebelum balok mengalami keruntuhan atau patah sama dengan momen penahan internal dari balok. Hal ini seperti pada Gambar 2.

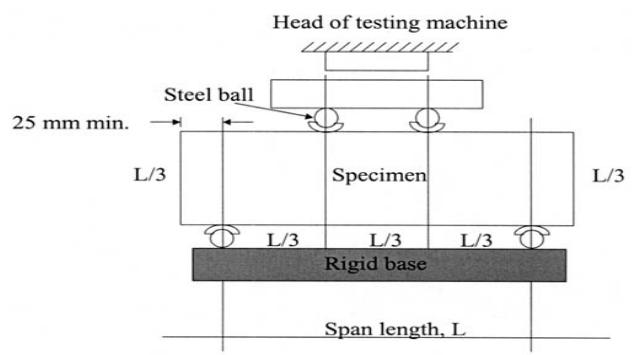

Gambar 2 Flexural strength test dengan alat Third Point Loading

Sumber: ASTM INTERNATIONAL, Designation: C $78-022010$

Rumus Flexural strength benda uji retak ditengah

$\mathrm{R}=\frac{101,97 \cdot P \cdot L}{b d^{2}}$

Rumus Flexural strength benda uji retak dipinggir

$\mathrm{R}=\frac{101,97, \vec{F}, 3 \cdot a}{b d^{2}}$

$\mathrm{R}=$ Flexural strength $\left(\mathrm{kg} / \mathrm{cm}^{2}\right)$

$101,97=$ Konversi dari $\mathrm{kn}$ ke $\mathrm{kg}$

$\mathrm{P} \quad=$ Beban pada waktu lentur $(\mathrm{kn})$

$\mathrm{L} \quad=$ Jarak dari perletakkan ke gaya $(\mathrm{cm})$

$\mathrm{b}=$ Lebar penampang balok $(\mathrm{cm})$

$\mathrm{d}=$ Tebal penampang balok $(\mathrm{cm})$

a $=$ Jarak antara retak ke pinggir terdekat benda uji $(\mathrm{cm})$

\section{METODOLOGI PENELITIAN}

\section{Jenis Penelitian}

Penelitian ini adalah penelitian yang dilakukan berdasrkan eksperimen di laboratorium. Penelitian dilakukan dengan membuat sampel beton untuk pengujian kuat lentur dengan benda uji berbentuk balok sedangkan benda uji bentuk silinder untuk pengujian kuat tekan.

\section{Sistematika Penelitian}

Obyek penelitian menganalisis pengujian kuat lentur beton dengan pengujian kuat tekan beton berdasarkan proporsi campuran pada pekerjaan perkerasan kaku jalan tol Balikpapan Samarinda. Pelaksanaan penelitian meliputi hal-hal yaitu persiapan bahan dan alat, perencanaan campuran, pembuatan benda uji, perawatan benda uji dan pengujian kuat tekan, analisis, dan pengambilan kesimpulan.

\section{Persiapan Bahan dan Alat}

Bahan yang digunakan, adalah:
a. Air
: dari PDAM
b. Semen
: PC merk Tonasa
c. Agregat Halus : Pasir Palu
d. Agregat Kasar : Kerikil Palu

Peralatan yang digunakan, adalah:

a. Timbangan

b. Cetok

c. Sekop dan cangkul

d. Concrete Mixer

e. Benda uji berbentuk balok dengan dimensi $15 \times$ $15 \times 60 \mathrm{~cm}$ untuk pemeriksaan kuat lentur beton dan silinder dengan dimensi $15 \times 30 \mathrm{~cm}$ untuk pemeriksaan kuat tekan beton.

f. Mesin uji kuat tekan dan kuat lentur Beton

\section{Perencanaan Campuran}

Pada penelitian ini perencanaan campuran beton berdasarkan proporsi perencanaan pada perkerasan kaku jalan tol Balikpapan - Samarinda.

\section{Pembuatan Benda Uji}

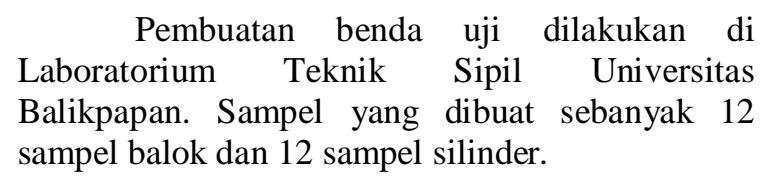

\section{Perawatan Benda Uji}

Perawatan benda uji dilakukan dengan merendam sampel di kolam perendaman yang berisikan air PDAM. Perendaman dilakukan 7, 14, 21, dan 28 hari. 
Kajian Kuat Lentur Beton pada Perkerasan Kaku...Rahmat ${ }^{(1)}$, Irna $\mathrm{H}^{(2)}$, Ryandi ${ }^{(3)}$

\section{Pengujian Sample}

Pengujian yang dilakukan adalah pengujian kuat lentur dan tekan beton. Kuat beton adalah perbandingan beban terhadap luas penampang beton. Pengujian kuat beton dilakukan terhadap benda uji yang sudah mencapai umur 7 , 14, 21, dan 28 hari.

\section{Analisa Hasil Test}

Hasil pengujian kuat lentur dan kuat tekan beton akan dilakukan analisis untuk menkaji bagaimana hubungan pengujian tersebut, dan membandingkan dengan persyaratan yang telah ditetapkan Dinas Pekerjaann Umum Provinsi Kalimantan Timur.

\section{Pembuatan Kesimpulan}

Setelah membuat analisis hasil penelitian, gambar grafik beserta penjelasannya, maka akan ditarik suatu kesimpulan tentang penelitian ini.

\section{HASIL PENELITIAN}

\section{Pengujian Material}

Pengujian material dilakukan untuk agregat kasar dan agregat halus. Pengujian material tersebut meliputi pengujian abrasi, kadar air, kadar lumpur, penyerapan dan analisa saringan. Hasil pengujian material terlihat pada Tabel 6 .

Tabel 6. Hasil Test pengujian material

\begin{tabular}{|c|c|c|c|c|}
\hline \multicolumn{2}{|c|}{ Jenis pengujian } & $\begin{array}{c}\text { Hasil } \\
\text { pengujian }\end{array}$ & Spesifikasi & Satuan \\
\hline \multicolumn{2}{|l|}{ Abrasi } & 18,4 & $<30$ & $\%$ \\
\hline \multirow[t]{2}{*}{ Kadar air } & $\begin{array}{l}\text { Agregat } \\
\text { kasar }\end{array}$ & 0,67 & Maks1 & $\%$ \\
\hline & $\begin{array}{l}\text { Agregat } \\
\text { halus }\end{array}$ & 2,67 & Maks 3 & $\%$ \\
\hline \multirow[t]{2}{*}{ Penyerapan } & $\begin{array}{l}\text { Agregat } \\
\text { kasar }\end{array}$ & 0,883 & - & $\%$ \\
\hline & $\begin{array}{l}\text { Agregat } \\
\text { halus }\end{array}$ & 2,208 & - & $\%$ \\
\hline \multicolumn{5}{|c|}{ Analisa saringan } \\
\hline \multirow{4}{*}{$\begin{array}{l}\text { Agregat } \\
\text { kasar }\end{array}$} & $11 / 2$ & 95,34 & $95-100$ & $\%$ \\
\hline & $3 / 4$ & 59,68 & $30-70$ & $\%$ \\
\hline & $3 / 8$ & 9,1 & $0-10$ & $\%$ \\
\hline & $\# 4$ & 4,67 & $0-5$ & $\%$ \\
\hline \multirow{7}{*}{$\begin{array}{l}\text { Agregat } \\
\text { halus }\end{array}$} & $3 / 8 "$ & 100 & 100 & $\%$ \\
\hline & $\# 4$ & 100 & $95-100$ & $\%$ \\
\hline & $\# 8$ & 94,92 & $80-100$ & $\%$ \\
\hline & $\# 16$ & 62,18 & $50-85$ & $\%$ \\
\hline & $\# 30$ & 34,37 & $25-60$ & $\%$ \\
\hline & $\# 50$ & 18,08 & $10-30$ & $\%$ \\
\hline & $\# 100$ & 8,06 & $2-10$ & $\%$ \\
\hline
\end{tabular}

Sumber : hasil pengujian

\section{Membuat Proporsi Campuran}

Setelah melakukan pengujian material, selanjutnya dilakukan perencanaan proporsi campuran. Hasil proporsi campuran didapatkan seperti Tabel 7.

Tabel 7 Tabel proporsi campuran

\begin{tabular}{lc}
\hline Slump & 6,5 \\
\hline Kadar air semen & 0,5 \\
\hline Berat air & $210 \mathrm{~kg}$ \\
\hline Berat semen & $480 \mathrm{~kg}$ \\
\hline Berat agregat kasar & $1096 \mathrm{~kg}$ \\
\hline Berat agregat halus & $523 \mathrm{~kg}$ \\
\hline Sumber :
\end{tabular}

Sumber : hasil analisis

\section{Pengujian Kuat Tekan dan Kuat Lentur Beton}

Pengujian kuat tekan beton untuk sampel beton silinder adalah berikut :

$$
\mathrm{Fc}=\frac{P \times 101,971}{A}
$$

$\mathrm{Fc} \quad=$ kuat tekan beton $\left(\mathrm{kg} / \mathrm{cm}^{2}\right)$

$\mathrm{P} \quad=$ Beban pada waktu lentur $(\mathrm{kn})$

A $\quad=$ luas permukaan $\left(\mathrm{cm}^{2}\right)=176.614 \mathrm{~cm}^{2}$

Tabel 8 Hasil pengujian kuat tekan beton

\begin{tabular}{|c|c|c|c|c|}
\hline $\begin{array}{c}\text { No. } \\
\text { sampel }\end{array}$ & $\begin{array}{c}\text { Umur } \\
\text { sampel } \\
\text { (hari) }\end{array}$ & $\begin{array}{c}\text { Berat } \\
\text { sampel } \\
(\mathbf{k g})\end{array}$ & $\begin{array}{c}\text { Dial } \\
\text { test } \\
(\mathrm{KN})\end{array}$ & $\begin{array}{c}\text { Kuat } \\
\text { lentur } \\
\text { beton } \\
\left(\mathrm{kg} / \mathrm{cm}^{2}\right)\end{array}$ \\
\hline 1 & 7 & 32,1 & 210 & $\begin{array}{l}121,18 \\
\end{array}$ \\
\hline 2 & 7 & 30,2 & 200 & 115,41 \\
\hline 3 & 7 & 31,1 & 230 & 132,72 \\
\hline \multicolumn{4}{|c|}{ Rata-rata 7 hari } & 123,10 \\
\hline 4 & 14 & 33,2 & 350 & 201,96 \\
\hline 5 & 14 & 32,4 & 355 & 204,85 \\
\hline 6 & 14 & 31,8 & 360 & 207,73 \\
\hline \multicolumn{4}{|c|}{ Rata-rata 14 hari } & 204,85 \\
\hline 7 & 21 & 32,7 & 420 & 242,36 \\
\hline 8 & 21 & 32,5 & 410 & 236,59 \\
\hline 9 & 21 & 33,2 & 420 & 242,36 \\
\hline \multicolumn{4}{|c|}{ Rata-rata 21 hari } & 240,43 \\
\hline 10 & 28 & 31,2 & 550 & 317,37 \\
\hline 11 & 28 & 32,5 & 525 & 302,95 \\
\hline 12 & 28 & 32,6 & 530 & 305,83 \\
\hline \multicolumn{4}{|c|}{ Rata-rata 28 hari } & 308,72 \\
\hline
\end{tabular}

Sumber: Hasil analisis. 
Kajian Kuat Lentur Beton pada Perkerasan Kaku...Rahmat ${ }^{(1)}$, Irna $\mathrm{H}^{(2)}$, Ryandi ${ }^{(3)}$

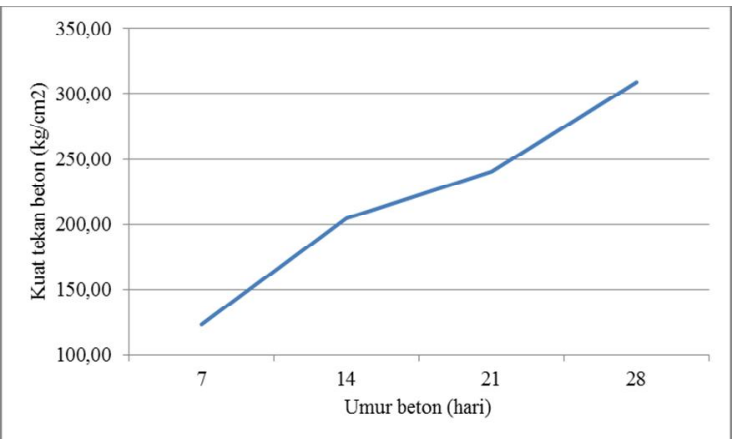

Gambar 3. Grafik hubungan kuat tekan beton dengan umur beton

Dari Gambar 3, terlihat bahwa kuat tekan beton bertambah seiring dengan bertambahnya umur beton.

Pengujian kuat lentur beton menggunakan persamaan:

$$
\mathrm{R}=\frac{101,971 \times P \times L}{b \times d^{2}}
$$

$\mathrm{R}=$ kuat lentur Balok $\left(\mathrm{kg} / \mathrm{cm}^{2}\right)$

$101,97=$ Konversi dari $\mathrm{kN}$ ke $\mathrm{kg}$

$\mathrm{P}=$ Beban pada waktu lentur $(\mathrm{kN})$

$\mathrm{L}=$ Jarak dari perletakkan ke gaya $(45 \mathrm{~cm})$

$\mathrm{b} \quad=$ Lebar penampang balok $(15 \mathrm{~cm})$

$\mathrm{d}=$ Tebal penampang balok $(15 \mathrm{~cm})$

Tabel 9 Hasil pengujian kuat lentur beton

\begin{tabular}{|c|c|c|c|c|}
\hline $\begin{array}{c}\text { No. } \\
\text { sampel }\end{array}$ & $\begin{array}{c}\text { Umur } \\
\text { sampel } \\
\text { (hari) }\end{array}$ & $\begin{array}{c}\text { Berat } \\
\text { sampel } \\
(\mathbf{k g})\end{array}$ & $\begin{array}{c}\text { Dial } \\
\text { test } \\
(\mathrm{KN})\end{array}$ & $\begin{array}{c}\text { Kuat } \\
\text { lentur } \\
\text { beton } \\
\left(\mathrm{kg} / \mathrm{cm}^{2}\right)\end{array}$ \\
\hline 1 & 7 & 32,10 & 22,00 & 29,91 \\
\hline 2 & 7 & 30,20 & 23,00 & 31,27 \\
\hline 3 & 7 & 31,10 & 24,00 & 32,63 \\
\hline \multicolumn{4}{|c|}{ Rata-rata 7 hari } & 31,27 \\
\hline 4 & 14 & 33,20 & 29,00 & 39,43 \\
\hline 5 & 14 & 32,40 & 29,00 & 39,43 \\
\hline 6 & 14 & 31,80 & 30,00 & 40,79 \\
\hline \multicolumn{4}{|c|}{ Rata-rata 14 hari } & 39,88 \\
\hline 7 & 21 & 32,70 & 35,00 & 47,59 \\
\hline 8 & 21 & 32,50 & 34,00 & 46,23 \\
\hline 9 & 21 & 33,20 & 37,00 & 50,31 \\
\hline \multicolumn{4}{|c|}{ Rata-rata 21 hari } & 48,04 \\
\hline 10 & 28 & 31,20 & 39,00 & 53,02 \\
\hline 11 & 28 & 32,50 & 40,00 & 54,38 \\
\hline 12 & 28 & 32,60 & 39,00 & 53,02 \\
\hline \multicolumn{4}{|c|}{ Rata-rata 28 hari } & 53,48 \\
\hline
\end{tabular}

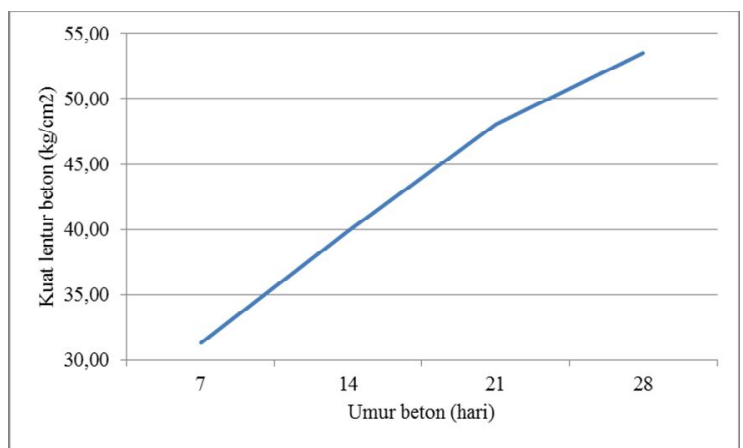

Gambar 4. Grafik hubungan kuat lentur beton dengan umur beton

Dari Gambar 4, terlihat bahwa kuat lentur beton bertambah seiring dengan bertambahnya umur beton.

\section{KESIMPULAN DAN SARAN}

1. Berdasarkan sampel benda uji yang dibuat dengan perencanaan campuran beton pada pekerjaan kaku jalan tol Balikpapan-Samarinda diperoleh kuat tekan beton sebesar $382 \mathrm{~kg} / \mathrm{cm}^{2}$, $27 \%$ lebih baik dan kuat lentur beton sebesar $53,48 \mathrm{~kg} / \mathrm{cm}^{2}, 18 \%$ lebih baik dari perencanaan campurannya.

2. Perkerasan kaku pada jalan tol BalikpapanSamarinda telah memnuhi persyaratan yang ditetapkan Dinas Pekerjaan Umum Provinsi Kalimantan Timur, yaitu kuat lentur beton minimal $45 \mathrm{~kg} / \mathrm{cm}^{2}$.

\section{DAFTAR PUSTAKA}

Abdulgani Helmi,_2011, "Mengenal kekuatan bahan (Compressive Strength)". Bandung.

ASTM INTERNATIONAL, Designation : C 293 02

Dinas Pekerjaan Umum Bidang Bina Marga, 1985, "Pedoman Perencanaan Perkerasan Kaku (Beton Semen)".

Dinas Pekerjaan Umum Bidang Bina Marga, 1993, "Buku Petunjuk Pelaksanaan Beton"

Dinas Pekerjaan Umum Bidang Bina Marga, 2010, "Spesifikasi Rev. 2" 
Kajian Kuat Lentur Beton pada Perkerasan Kaku...Rahmat ${ }^{(1)}$, Irna $\mathrm{H}^{(2)}$, Ryandi ${ }^{(3)}$

Dinas Pekerjaan Umum Bidang Bina Marga, 2015, "Spesifikasi Jalan Tol Bina Marga".

Irna Hendriyani, 2016, "Modul Praktikum Teknologi Beton", Balikpapan, Program Studi Teknik Sipil Fakultas Teknik Sipil dan Perencanaan Universitas Balikpapan.

Irna Hendriyani; Reno Pratiwi; Yepi Aprilianus, 2016, "Pengaruh Jenis Air pada Perawatan Beton terhadap Kuat Tekan Beton", Jurnal Transukma Vol. 01 No. 02 hal. 202 - 212 Juni 2016, Balikpapan; Program Studi Teknik Sipil Fakultas Teknik Sipil dan Perencanaan Universitas Balikpapan.

Rahmat; Irna Hendriyani; Moch. Syaiful Anwar, 2016, “Analisis Kuat Tekan Beton dengan Bahan Tambah Reduce Water dan Accelerated Admixture", Jurnal Info Teknik Vol. 17 N0. 02 Desember 2016, Banjarbaru ; Fakultas Teknik Universitas Lambung Mangkurat.

Syahputra Reza, 2010, Perkerasan Kaku, Jakarta, Bumi Aksara.

Tri Mulyono, 2004, Teknologi Beton, Yogyakarta, Andi. 